Mieczysław Paczkowski*

Wrocław-Toruń

\title{
Proces ksztaltowania woli i wyrabiania nawyków według Orygenesa
}

Od chwili powstania imperium rzymskie starało się uchodzić za społeczność, w obrębie której wychowywano narody i jednostki. Korzystając szeroko z paradygmatu dydaktycznego, stosowano wszelkie środki, aby osiągnąc consensus lub przynajmniej podporządkowanie się sprzymierzeńców i poddanych ${ }^{1}$. Pojawiały się elementy szerokiego i metodycznego „dydaktyzmu” politycznego ${ }^{2}$. Należy do tego dołączyć ogólną atmosferę kulturową epoki, która niemal automatycznie ukierunkowywała ku dydaktyzmowi w filozofii, literaturze i sztukach plastycznych ${ }^{3}$. Niewątpliwie wczesne chrześcijaństwo było podatne na te wpływy ${ }^{4}$.

* Franciszkanin (OFM), studiował w Jerozolimie i w Rzymie. Wykładał patrologię, teologię wschodnią i historię egzegezy w kraju i za granica. Obecnie wykładowca WT UMK.

1 „Ty, pomnij, Rzymianinie, nad ludami władać. To sztuka godna ciebie: prawa pokoju stanowić, oszczędzać zwyciężonych, a dumnych poskramiać (Tu regere imperio populos, Romane, memento - hae tibi erunt artes - pacique imponere morem, parcere subiectis et debellare superbos)"; Wergiliusz, Aeneis VI, 851-853; por. W. Markowska (przekł.), Wergiliusz. Eneida, Warszawa 1970, s. 141.

${ }^{2}$ Do tego zjawiska należy zaliczyć anachroniczne nawiązywanie do przeszłości związanej z republiką przez Oktawiana Augusta, Klaudiusza, Hadriana, Decjusza lub paternalizm czy filozoficzna poza Wespazjana i Tytusa, Nerwy, Antonina Piusa, Marka Aureliusza i cesarzy z dynastii Sewerów.

${ }^{3}$ Jest to epoka neoarystotelizmu Aleksandra z Afrodyzji, neoepikureizmu Diogenesa, neostoicyzmu Seneki, Epikteta i Marka Aureliusza, neopirronizmu Sykstusa Empiryka, neocynizmu Diona i Peregrinosa (Proteosa), średniego platonismu i neopitagoryzmu Numeniusza z Apamei i Albinosa. Dodać do tego należy hermetyzm i popularność tzw. Wyroczni Chaldejskich.

${ }^{4}$ Por. F. Pierini, El maestro en la patristíca y en la tradición eclesial (especialmente en el „,De Magistro" de San Agustín y de Santo Tomás de Aquino), wg http://mscperu.org/biblioteca/1 catequetica/maestro/031supuestos_ped_eclesial.htm\#n1 (13 XII 2006 r.). 


\section{Ogólne spojrzenie na paradygmat dydaktyczny we wczesnym chrześcijaństwie}

Rodzące się chrześcijaństwo stanęło w obliczu bogatej greckiej i żydowskiej tradycji edukacji i wychowania5. Także wyższy stopień formacji i wykształcenia, czyli przynależność do którejś ze szkół filozoficznych, wiązało poznanie teoretyczne w pierwiastkiem moralnym. W myśl zhellenizowanej tradycji żydowskiej filozofia miała prowadzić ku dobremu życiu oświeconemu przez wiarę ${ }^{6}$.

Na podstawie najstarszych świadectw wiadomo, że pouczenia i katecheza były zarezerwowane dla ,nauczycieli” (didaskaloi), posiadających specjalny charyzmat (por. 1 Kor 9, 21). Pisma epoki poapostolskiej wyszły spod pióra tych, którzy posługiwali przez nauczanie ${ }^{7}$. Oni to właśnie zaczęli zwracać uwagę na pedagogiczne działanie Boże. Wyrażenia typu „Boża paideia” czy „paideia Chrystusa” znajdują się nie tylko w pismach Nowego Testamentu (przede wszystkim w listach deutero-pawłowych i pasterskich), lecz również w jednym z pierwszych dzieł okresu poapostolskiego, zwanym Listem Klemensa Rzymskiego i napisanym około 96 roku (ostatnie rozdziały) ${ }^{8}$. Kolejne przykłady tego typu można uważać za rozwinięcie chrześcijańskiej paidei. Anonimowy autor Listu do Diogneta określa siebie jako „nauczyciela pogan”. Zdaniem Ireneusza, nauczyciele wspólnot (biskupi) gwarantują ,nieomylny charyzmat prawdy" ${ }^{\prime \prime}$.

W teologii judeochrześcijańskiej Chrystus przedstawiany był jako Prawo (Nomos) ${ }^{11}$. Natomiast $\mathrm{w}$ chrześcijaństwie greckim i łacińskim coraz większego znaczenia nabierało ukazywanie Chrystusa jako mistrza. Określenia Zbawiciela jako przewodnika i nauczyciela były wykorzystywane w polemice z Żydami, natomiast wskazanie na Niego jako na odwieczny $\operatorname{Logos}^{12}$ stanowiło ważny argument w dyskusji z poganami.

${ }^{5}$ Septuaginta, posługując się słowem paideia, oddaje znaczenie hebrajskiego wyrazu musar, oznaczającego zabiegi mające doprowadzić grzesznika do zmiany sposobu myślenia. Por. H. I. Marrou, Historia wychowania w starożytności, Warszawa 1969, s. 233.

${ }^{6}$ Por. Justyn, I Apologia 2,1; Klemens Aleksandryjski, Paedagogus III, 11, 78; Orygenes, Contra Celsum IV, 31; Grzegorz Taumaturg, Oratio panegyrica in Origenem 9.

${ }^{7}$ Justyn wskazuje, że nauczenie było ściśle związane z celebracją eucharystyczną. Por. I Apologia 67.

${ }^{8}$ Por. W. Jaeger (K. Bielawski [przekł., red. i wprow.]), Wczesne chrześcijaństwo i grecka paideia, Bydgoszcz 2002, s. 36-37.

${ }^{9}$ Ad Diognetum 11. Por. K. Bihlmeyer (wyd.), Die apostolischen Väter. Neubearbeitung der funkschen Ausgabe Erster Teil: Didache, Barnabas Klemens I und II, Ignatius, Polykarp Papias, Quadratus, Diognetbrief (Sammlung ausgewählter kirchen- und dogmengeschichtlicher Quellenschriften: Zweite Reihe), Tübingen 1924. Autor cytowanego dzieła czasami był identyfikowany z Pantajnosem - założycielem teologicznej „szkoły aleksandryjskiej”.

10 „Charisma veritatis certum”; Adversus haereses IV, 26, 2. Na temat tego określenia por. N. Brox, Charisma veritatis certum (Zu Irenäus Adv. haer. IV, 26, 2), Zeitschrift für Kirchengeschichte 75 (1964), s. 327-331.

${ }^{11}$ Por. J. Daniélou, Teologia judeochrześcijańska (Myśl teologiczna 39), Kraków 2002, s. 220 -223 .

${ }^{12}$ Widać tu przemożny wpływ Filona z Aleksandrii, żyjącego w epoce św. Pawła Apostoła. 
Filozof, męczennik i apologeta Justyn posługuje się tymi dwoma wizerunkami Syna Bożego. Pierwsze porównanie znajduje zastosowanie w Dialogu z Tryfonem ${ }^{13}$, a drugie w Apologiach ${ }^{14}$ (odnośnie do logos spermatikòs) $^{15}$. W obu przypadkach Chrystus jest urzeczywistnieniem paidei, skierowanej do Żydów i pogan ${ }^{16}$.

Ireneusz, biskup Lyonu (zm. ok. 202 r.), stoi na czele autorów zwalczających fałszywą gnozę. Przedstawia tych błędnowierców jako „złych thumaczy tego, co zostało dobrze powiedziane" ${ }^{17}$. Kolejnym emanacjom z Pełni (Pleroma) i niekończącym się genealogiom eonów polemista przeciwstawia Chrystusa - Słowo, a przeciwko dualizmowi, tak charakterystycznemu dla wielu grup gnostyckich, podkreśla jedność paidei Bożej w historii zbawienia ${ }^{18}$. Odkupienie ofiarowane zostaje wszystkim ludziom przez Jezusa Chrystusa, jedynego Mistrza i w jednym nauczającym Kościele ${ }^{19}$.

Wszyscy pisarze starochrześcijańscy epoki przednicejskiej, jeśli tylko mieli okazję, podkreślali potrzebę naśladowania Chrystusa. W okresie niemal nieustannych prześladowań Kościoła męczennicy byli uważani za najdoskonalszych naśladowców Boskiego Mistrza $^{20}$. Inną cechą charakterystyczną wychowania chrześcijańskiego było wpajanie karności w życiu moralnym ${ }^{21}$.

Refleksje odnoszące się do paidei chrześcijańskiej znajdują swój najpełniejszy wyraz w środowisku aleksandryjskim. To właśnie w metropolii Egiptu „chrześcijaństwo wywodzące się z kręgów semickich dopełniło swojej greckiej edukacji”22. Obok Muzeionu, działał tam także hebrajski Bet-midrasz ${ }^{23}$ czyli ośrodek studiów, gdzie Filon poznał i zaakceptował interpretację alegoryczną Bibliii ${ }^{24}$. W centrum kultury

${ }^{13}$ Por. J. Quasten, Patrologia, t. 1, Casale Monferrato 1983, s. 180-181. Por. również G. Visonà (wstęp, tłum. wł. i przypisy), Giustino. Dialogo con Trifone, Mediolan 1988.

${ }^{14}$ Odnośnie do Apologii Justyna por. L. Alfonsi, La struttura della I Apologia di Giustino, w:

R. Cantalamessa (wyd.), L. F. Pizzolato (wyd.), Paradoxos politeia. Studi in onore di Giuseppe Lazzati, Mediolan 1979.

${ }^{15}$ Por. M. C. Paczkowski, „Logos obecny w każdym człowieku”. Justyn Męczennik o mądrości i sprawiedliwości wśród niechrześcijan, Collectanea Theologica 2/2006, s. 131-145.

${ }^{16}$ Por. P. Chiocchetta, Teologia della storia. Saggi di sintesi patristiche, Rzym 1953, s. 15-36.

${ }^{17}$ Por. Adversus haereses I, prol. 1. Poszczególne części dzieła Ireneusza w: A. Rousseau, L. Doutreleau, B. Hemmerdinger, Ch. Mercier (wyd.), Irénée de Lyon. Contre les hérésies, t. 1-10 (SC [= Sources Chrétiennes $]$ 50;100;101; 152; 153; 210; 211; 263; 264; 293; 294), Paryż 1965; 1969; 1974; 1979; 1982.

${ }^{18}$ Według błędnowierczej koncepcji zbawienia, polegało ono na wyzwoleniu „doskonałego gnostyka”. Por. Adversus haereses I, 21, 1-5.

${ }^{19}$ Por. P. Chiocchetta, Teologia della storia..., s. 37-70.

${ }^{20}$ Por. M. Pellegrino, L'imitation du Christ dans les Actes des Martyrs, La Vie Spirituelle 98/1958, s. $38-54$.

${ }^{21}$ Por. H. J. Marrou, Historia wychowania w starożytności..., s. 435.

22 J. Daniélou, H. I. Marrou, Historia Kościoła, t. 1, Warszawa 1984, s. 111.

${ }^{23} \mathrm{Na}$ temat diaspory żydowskiej w Aleksandrii por. Por. J. Mélèze-Modrzejewski, La communauté Juive, w: Alexandrie, lumière du monde antique, Les Dossiers d'Archéologie 201/3 (1995), s. 44-48.

${ }^{24}$ Por. przede wszystkim S. Matuszewski, Filozofia Filona z Aleksandrii i jej wptyw na wczesne chrześcijaństwo, Warszawa 1962; S. Sandmel, Philo Judaeus. An Introduction to the Man, His Writings, and His Significance, w: Aufstieg und Niedergang der römischen Welt, II: Principat, Berlin 1984, s. 731-759; R. Williamson, Jews in the Hellenistic World, II: Philo, Cambridge 1989. 
i refleksji intelektualnej, jakim była metropolia Egiptu, było niemal nieuniknione powstanie na początku III wieku chrześcijańskiej instytucji o charakterze katechetycznym i teologicznym o nazwie Didaskaleion ${ }^{25}$. Był to rodzaj wszechnicy edukacyjnej $^{26}$, do której mogli uczęszczać praktycznie wszyscy.

W Aleksandrii ${ }^{27}$ pojawili się dwaj najwybitniejsi przedstawiciele chrześcijańskiego nurtu paidei: Klemens Aleksandryjski i Orygenes. To właśnie oni podjęli kompleksowy i zaangażowany wysiłek, aby stworzyć teoretyczne i praktyczne zasady paidei w duchu Ewangelii, które mogłyby stawić czoła pogaństwu i judaizmowi w konfrontacji z ich sposobem przekazywania i rozwoju kultury, myśli religijnej i moralności.

Klemens Aleksandryjski (zm. ok. 215 r.) uważany jest za jednego z najbardziej reprezentatywnych myślicieli środowiska aleksandryjskiego. To właśnie on opracował rodzaj encyklopedii dotyczącej sylwetki Boskiego Nauczyciela - Logosu, Boga, który stał się człowiekiem. Przystosowując popularny wśród szkół filozoficznych schemat, rozpoczął od przekonywania i przygotowania (Protreptyk), aby następnie ukazać Chrystusa jako Nauczyciela wszystkich (Pedagog) ${ }^{28}$. Trzecia część obejmowała nauczanie typu ezoterycznego i pogłębienie problematyki dotyczącej kultury umysłowej Hellenów i objawienia Bożego (Chrystus - didaskalos). Teologia Klemensa ma charakter chrystologicznej pedagogiki, a motyw paidei przewija się przez wszystkie jego dzieła ${ }^{29}$. Podłożem inspirującym jest filozofia typu eklektycznego i chociaż brak mu systematyczności, jednak dzięki ogromnej erudycji, oferuje wiele kluczowych perspektyw dla analizy tradycji starożytnego chrześcijaństwa i jego konfrontacji z kulturą klasyczną grecką i rzymską ${ }^{30}$.

Klemens nadzwyczaj cenił działalność formacyjną i wychowawczą: „Najlepsze i najdoskonalsze z dóbr życia nazwaliśmy pedagogią, a więc nauczaniem i wychowaniem" ${ }^{\prime 3}$. Jego wysiłki szły w stronę opracowania strategii wykształcenia podstawowego i wyższego stopnia poznania (gnosis), aby prawdę chrześcijańską można przekazywać na wszystkich poziomach i kierunkach ${ }^{32}$. Czynił to ze świadomością, że „dla całego rodzaju ludzkiego [...] konieczne są kultura i cnota”33. Jednak błędne

${ }^{25}$ Szkołą aleksandryjską kierowali jako didaskaloi: Pantajnos (ok. 180 r.), Klemens Aleksandryjski (200-202), Orygenes (202-231), Heraklas, Aleksander, Dionizy, Pieriusz, Teognost, Achillas, Serapion, Piotr, Makariusz, Dydym Ślepy (zm. w 398 r.) i Rodon, który przenosi się w 405 do Side w Panfilii.

${ }^{26}$ Por. J. M. Szymasiak, M. Starowieyski (red.), Stownik wczesnochrześcijańskiego piśmiennictwa, Poznań 1977, s. 299.

${ }^{27} \mathrm{Na}$ temat roli Aleksandrii por. M. Simonetti, Alessandria, w: A. Di Berardino (red.), Dizionario Patristico e di Antichità cristiane, t. 1, Casale Monferrato 1984.

${ }^{28}$ Odnośnie do powyższej tematyki por. L. Rzodkiewicz, Jezus Chrystus w kulturze antycznej. Stanowisko Klemensa Aleksandryjskiego (Biblioteka diecezji legnickiej 10), Legnica 1999, s. 81-95; 116-123.

${ }^{29}$ Por. W. Völker, Der wahre Gnostiker nach Clemens Alexandrinus, Berlin-Lipsk 1952, s. 99.

${ }^{30}$ Por. P. Chiocchetta, Teologia della storia..., s. 74-104.

${ }^{31}$ Paedagogus I, 16.

${ }^{32}$ Por. J. Daniélou, Messaggio evangelico e cultura ellenistica, Bolonia 1975, s. 521-540.

${ }^{33}$ Stromata IV, 63. Por. P. Th. Camelot (wstęp), C. Mondésert (wyd. i tłum.), Clément d'Alexandrie. Les Stromates II (SC 38), Paris 1954. 
postępowanie wielu ludzi jest niezaprzeczalnym faktem, dlatego nasz autor szuka jego genezy. Dochodzi do wniosku, że należy wskazać na braki intelektualnej strony człowieka oraz niedomogi jego strony moralnej. Pokonanie tych błędów widzi na drodze dwóch działań: kształcenia umysłu i wychowania ${ }^{34}$. Tylko Chrystus zharmonizował w swoim życiu pełnię intelektualną z doskonałością moralną. Dlatego Klemens proponuje osiągnięcie doskonałego człowieczeństwa poprzez naśladowanie Jego życia ${ }^{35}$ i uzyskanie z Nim pełnej jednomyślności ${ }^{36}$. To działanie Zbawiciela doprowadza ludzką osobowość do doskonałej harmonii ${ }^{37}$. W ten kompleksowy sposób Klemens ukazuje Jezusa Chrystusa jako mistrza i wychowawcę, a chrześcijaństwo jako prawdziwą paideię.

\section{Orygenes jako didaskalos}

Myśl Orygenesa (zm. 254 r.) reprezentuje wyższe stadium rozwoju i rozwija w sposób szerszy i systematyczniejszy ideę paidei chrześcijańskiej, której perspektywy poszerzył w tak znaczący sposób Klemens Aleksandryjski ${ }^{38}$. Orygenes stosuje w sposób całościowy metodologię uczonych i erudytów swojej epoki, formułując szeroki i jasno określony system formacji, który wprowadzał w życie najpierw w rodzinnej Aleksandrii (lata 203-231) ${ }^{39}$, a następnie w Cezarei Nadmorskiej w Palestynie (w okresie 232-253).

${ }^{34}$ Klemens przedstawia swój punkt widzenia, opierając się na zasadzie tezy i antytezy: „Choć niezliczona jest ilość czynów ludzkich, to jednak tylko dwa są źródła prawie wszystkich błędów: brak wiedzy i słabość woli, obydwa zależne są od nas, gdyż ludzie albo nie chcą się uczyć, albo nie chcą opanować namiętności. Z tych dwu braków w wypadku pierwszego nie uzyskują ludzie właściwego sądu, w wypadku drugiego nie są w stanie podążać za tym sądem, który prawidłowo wyprowadzili” (Stromata VII,101). „Zgodnie z tym są do dyspozycji dwie odmienne zasady wychowawcze w stosunku do każdego z dwu błędów. Oto w pierwszym wypadku przekaz gnozy i powoływanie się na niezbity dowód w postaci świadectwa ksiąg świętych, z drugiej strony stosowanie rozumnych ćwiczeń, jako następstwo wychowania w wierze i bojaźni Bożej” (tamże VII,102).

${ }^{35}$ „Iść [...] prawdziwie za Zbawicielem, to dążyć do Jego bezgrzeszności i doskonałości, a patrząc weń jak w zwierciadło, tak upiększać duszę swoją, ład w niej przywracać i wszystko na wszelkie sposoby kształtować podobnie do Niego" (Quis dives salvetur 21, 7).

${ }^{36}$ Por. Stromata IV, 132.

37 „Jeśli staliśmy się słuchaczami Logosu, wychwalajmy szczęśliwy plan zbawienia, przez który człowiek zostaje wychowany i przez co uzyskuje prawa obywatelskie w niebie i tam otrzymuje Ojca, którego na ziemi [przez Chrystusa] poznał. Pod każdym względem Logos jest Stwórca, Nauczycielem i Wychowawcą" (Paedagogus III, 99).

${ }^{38}$ Por. W. Jaeger, Wczesne chrześcijaństwo i grecka paideia..., s. 74.

${ }^{39}$ W Didaskaleionie Orygenes wykładał sztuki wyzwolone, filozofię i Pismo Święte. Por. J. M. Szymasiak, M. Starowieyski, Słownik wczesnochrześsijańskiego piśmiennictwa..., s. 299. Według relacji Euzebiusza z Cezarei, Orygenes ,tych ze swoich uczniów, w których dostrzegał odpowiednie zdolności, wprowadzał w wiedzę filozoficzną, wykładał im geometrię, arytmetykę i inne nauki przedwstępne, potem prowadził ich dalej do rozmaitych systemów filozoficznych, wykładał ich pisma, a każde z nich objaśniał i jak najstaranniej pogłębiał, tak że nawet wśród Greków zyskał imię wielkiego filozofa. Wielu mniej uzdolnionych uczniów prowadził [...] drogą zwykłych nauk szkolnych i mówił im, że nauki te będą dla nich bardzo pożyteczne, bo im dadzą głębsze zrozu- 
Według Hieronima, Adamancjusz opanował w sposób doskonały nauki ścisłe, gramatykę i teorię wszystkich systemów filozoficznych. To powód, dla którego „miał [on] także słuchaczy spośród ludzi oddających się nauce literatury świeckiej” ${ }^{40}$. Orygenes był przekonany, że nauki z curriculum studiów świeckich mają służyć przygotowaniu do chrześcijaństwa i stanowią niezbędne narzędzie do lepszej interpretacji Pisma Świętego ${ }^{41}$. Za najprzydatniejsze autor aleksandryjski uznawał gramatykę i dialektykę (logikę) ${ }^{42}$. „Także dla siebie samego ćwiczenie w naukach świeckich i filozoficznych uważał za rzecz niezbędnie potrzebną"43.

Opis paidei firmowanej imieniem Orygenesa pozostawił Grzegorz Cudotwórca ${ }^{44}$. Ten pilny uczeń i zwolennik Aleksandryjczyka informuje o metodzie nauczania Orygenesa, toku studiów, wykładanych w jego szkole przedmiotach. Według słów ucznia Orygenesa Grzegorza Taumaturga, jego mistrz był człowiekiem otwartym i dialogującym ze światem.

Ten zaś mistrz, skoro tylko przyjął nas do grona swych uczniów, począł od pierwszego dnia czynić wszelkie wysiłki, by nas jak najbardziej zbliżyć ku sobie [...]. Oswajał nas zaś przeróżnymi sposobami, używając wszelkich rodzajów perswazji i poruszając, że tak powiem, wszystkie struny naszej duszy. Wychwalał, jak mógł, filozofię i jej miłośników [...]. Słowa jego trafiały w nas niby jakieś pociski, gdyż miały w sobie i ujmującą słodycz, i zdolność przekonywania, i sugestywną siłę [...]. Porywał nas, gdy

mienie ksiagg świętych, oraz przygotowanie do nich”. Historia ecclesiastica VI, 18. Por. G. Bardy (wyd. i opr.), Eusèbe de Césarée. Histoire ecclésiastique: livres V-VII tom (SC 41), Paryż 1955; A. Lisiecki (tłum., wstęp i opr.), Euzebiusz z Cezarei. Historia kościelna. O męczennikach palestyńskich (Pisma Ojców Kościoła 3), Poznań 1924 [reprint: Kraków 1993].

${ }^{40}$ De viris illustribus 55. Cytat wg J. M. Szymasiak, M. Starowieyski (red.), Stownik wczesnochrześcijańskiego piśmiennictwa..., s. 296. Ta opinia potwierdza relację Euzebiusza z Cezarei: „Wielu uczonych pociaggał powszechny rozgłos Orygenesa, więc szli do niego, by się przekonać o jego biegłości w świętych naukach. Tysiące heretyków i wielu co najznakomitszych filozofów skwapliwie się do niego garnęło, biorąc u niego naukę nie tylko w teologii, ale także w filozofii pogańskiej”. Historia ecclesiastica VI,18.

${ }^{41}$ Por. Philocalia 13, 1. Na temat Filokalii por. J. Gribomont, L'origenisme de Saint Basile, w: L'homme devant Dieu. Mélanges H. de Lubac, Paryż 1963, s. 282-285.

${ }^{42}$ Por. Philocalia 14, 2. Por. M. Harl, N. de Lange (wyd.), Origène. Philocalie, 1-20: Sur les Écritures; La lettre à Africanus sur l'histoire de Suzanne (SC 302), Paryż 1983; K. Augustyniak (tłum. i wstęp), Orygenes. Filokalia, Warszawa 1979. O konieczności studiów gramatycznych wspomina także Tertulian (por. De idolatria 10).

${ }^{43}$ Euzebiusz z Cezarei, Historia ecclesiastica VI, 18.

${ }^{44}$ W Cezarei Nadmorskiej Grzegorz wysłuchał kilku wykładów Orygenesa. Fakt ten wpłynął na zmianę jego planów życiowych, przyczyniając się do rezygnacji z zamierzonych studiów w Bejrucie. Mowa na cześć Orygenesa autorstwa Grzegorza jest oceniana jako ważne źródło dla historii pedagogiki chrześcijańskiej. Ojcowie Kapadoccy czcili Grzegorza Cudotwórcę jako założyciela Kościoła w ich ojczystych stronach. W III wieku wspólnota kapadocka była kierowana przez Firmiliana, przyjaciela i ucznia Orygenesa, współczesnego Grzegorzowi Cudotwórcy. Por. J. Quasten, Patrologia, t. 1, s. 391-392; P. Nautin, Firmiliano di Cesarea di Cappadocia, w: A. Di Berardino (red.), Dizionario Patristico e di Antichità cristiane, t. 1, Casale Monferrato 1984, kol. 1378-1379. Por. Historia ecclesiastica VI, 27. 
dowodził [...], że bez filozofii niepodobna nawet Boga czcić w odpowiedni sposób, a więc korzystać z przywileju, jaki wśród wszystkich istot ziemskich jedynie człowiek otrzymał, i to każdy człowiek, tak wykształcony jak prosty, jeśli tylko ma zdrowe zmysły. $\mathrm{Na}$ wszystko, co twierdził, przytaczał mnóstwo argumentów ${ }^{45}$.

Z lektury słów Cudotwórcy nasuwa się wniosek, że ma się do czynienia z zalążkiem uniwersytetu o charakterze chrześcijańskim ${ }^{46}$.

Plan studiów proponowany przez Orygenesa pokrywał się z programem pogańskich szkół retoryki ${ }^{47}$. Nie chodziło jednak o nauczane przedmioty ${ }^{48}$, ponieważ duch tych nauk i cel przyświecający studiom były odmienne niż pogańskie. Nauczanie Orygenesa przenikał duch eklezjalny i chrześcijański, a celem było osiagnięcie głębszego poznania nauki Ewangelii przedstawionej przez Chrystusa-Mistrza ${ }^{49}$. Tak oto plan całej struktury formacji człowieka i stopniowego wyzwalania ludzkiej woli powiązany został z przesłaniem zbawienia. Owo pojmowanie chrześcijaństwa jako paidei ludzkości pozwalało Aleksandryjczykowi na ustalenie związku przekonań zwolenników Platona i stoików z Pismem Świętym i obrazem Jezusa, jaki dają Ewangelie. Zbawiciel ma jednak nie tylko rysy nauczyciela ludzi, jest bowiem wcielonym Logosem, co w istotny sposób różni chrześcijaństwo od wszelkiej ludzkiej filozofii i metody formacyjnej ${ }^{50}$.

Grzegorz podkreśla siłę perswazji Orygenesa, co wynikało z jego uczestnictwa w Logosie.

Nie usiłował nas bynajmniej zwyciężać siłą swej wymowy, lecz tylko starał się z całą roztropnością, życzliwością i ludzką wyrozumiałością chronić nas od zguby i umożliwiać nam korzystanie $\mathrm{z}$ dóbr zarówno tych, jakie daje filozofia, jak przede wszystkim tych, których Bóg jemu samemu użyczył [...]. Mam tu na myśli zwłaszcza ów zbawczy Logos, Mistrza wielkiej pobożności ${ }^{51}$.

${ }^{45}$ Oratio panegyrica in Origenem 6. Por. H. Crouzel (wyd.), Grégoire le Thaumaturge. Remerciement à Origène suivi de la lettre d'Origène à Grégoire (SC 148), Paryż 1969.

${ }^{46}$ Por. J. M. Szymasiak, M. Starowieyski, Stownik wczesnochrześcijańskiego piśmiennictwa..., s. 299; F. Pierini, El maestro en la patristíca y en la tradición eclesial... (wersja elektroniczna).

${ }^{47}$ Czerpały one inspirację ze średniego platonizmu reprezentowanego przez Albinosa, Maksyma z Tyru, Numeniusza oraz ze stoicyzmu Anneusza Kornuta i Chairemona czy neopidagoryzmu Filostrata.

${ }^{48}$ Były to: logika, fizyka, etyka i metafizyka. W metodologii królował niepodzielnie alegoryzm.

${ }^{49}$ Por. J. Daniélou, Origène, Paryż 1948.

${ }^{50}$ Platon w Prawach nauczał, że Logos stanowi złote ogniwo, poprzez które Prawodawca i Nauczyciel oraz Jego dzieła powiązane są z boskim Rozumem (por. Leges I, 645 a-c). Kosmos Platona, przedstawiony w Temajosie, umożliwia wychowanie człowieka, ponieważ dla swej realizacji wymaga ono świata uporządkowanego, a nie chaotycznego. Bóg jest ostatecznym źródłem paidei: ,jest pedagogiem wszechświata” (Leges X, 897 c). Por. W. Jaeger, Wczesne chrześcijaństwo i grecka paideia..., s. 80 .

${ }^{51}$ Oratio panegyrica in Origenem 6. 
Orygenes pociagał więc własnym przykładem i swoje nauki wprowadzał w czyn, starając się upodobnić do ideału, jaki przedstawiały. Dla swoich uczniów stanowił wzór wszelkich cnót i tym samym pobudzał w nich umiłowanie i pragnienie doskonałości ${ }^{52}$.

Autorowi tego literackiego portretu nie chodzi bynajmniej o idealizację. Jest to raczej charakterystyka doskonałego nauczyciela i wychowawcy, od którego wychowankowie mogą przejąć nie tylko wiedzę, ale również styl życia i obyczaje.

Nic dziwnego, że w takich warunkach musiała od razu niby jakaś iskra wpaść w serce moje i rozniecić w nim płomień miłości nie tylko ku wspomnianemu świętemu Logosowi, pięknością swą pociagającemu wszystkich z nieodpartą mocą, ale także ku człowiekowi, będącemu tegoż Logosu przyjacielem i heroldem zarazem. Ta to właśnie miłość skłoniła mię ostatecznie do zrezygnowania ze wszystkich planowanych dotychczas studiów i zajęć [...]. Jedno tylko było mi odtąd drogie i jedno tylko cenne: filozofia oraz mój w niej mistrz, człowiek prawdziwie z nieba zesłany ${ }^{53}$.

Grzegorz nie podziwia u Orygenesa rozległej erudycji i wiedzy spekulatywnej, lecz zdolności do formowania umysłów oraz kierowania duchem i pragnieniami uczniów. Nauka prowadziła ku wyrobieniu duchowemu, a sam didaskalos jawi się jako herold Słowa i cnót, przewodnik moralnego i religijnego zastosowania filozofii ${ }^{54}$.

Swoisty program pedagogiczny i formacyjny realizowany przez Orygenesa to droga naśladowania Chrystusa i posłuszeństwa Mu. Integralną częścią tego procesu jest asceza. Znamienny jest fakt, że udokumentowano krag ascetyczny, który utworzył się wokół Orygenesa, uważanego nie tylko za wielkiego teologa i egzegetę, ale także za mnicha ante litteram i prekursora życia ascetycznego. Opis heroiczności życia Aleksandryjczyka wyszedł spod pióra pisarza palestyńskiego - Euzebiusza z Cezarei. „Jego czyny świadczyły o zadziwiającej doskonałości jego najprawdziwszej filozofii ${ }^{55}$. Powiadano: Jakie słowo, takie życie; jakie życie, takie i słowo" ${ }^{56}$.

Euzebiusz kreśli fascynujący portret Orygenesa - ascety i poszukiwacza prawdy:

Spostrzegł [on], że zajmowania się retoryką nie można pogodzić z pracą nad nauką Bożą. Przeto bez żadnej już zwłoki zaniechał nauczania umiejętności gramatycznych, jako nieużytecznych i przeszkadzających naukom świętym [...]. Sprzedał wszystkie, jakie tylko miał, dzieła starożytnych pisarzy, którymi się przedtem tak gorliwie zajmował [...]. Przez długie lata wiódł filozoficzny tryb życia, tłumiąc w sobie wszelką skłonność do młodzieńczych namiętności. Za dnia oddawał się wytężonej pracy nauczycielskiej, a większą część nocy poświęcał badaniu Bożych Pism. Wiódł życie najwstrzemięźliwsze,

${ }^{52}$ Por. H. Crouzel, Orygenes, (tłum. J. Margański), Bydgoszcz 1996, s. 54.

${ }^{53}$ Oratio panegyrica in Origenem 6.

${ }^{54}$ Por. H. Crouzel, Orygenes..., s. 53.

${ }^{55}$ Filozoficzny tryb życia oznaczał ascezę.

${ }^{56}$ Historia ecclesiastica VI, 3. Chodzi o przysłowie greckie, oświadczone przez Senekę; por. Epistula 94': „Apud Graecos in proverbium cessit: Talis hominibus fuit oratio, qualis vita”. 
ćwicząc się w postach, bądź to skracając czas przeznaczony na sen [...]. Najchętniej nie kładł się na posłanie, ale na gołą ziemię [...]. Według jego opinii, należało zachowywać słowa Zbawiciela [...]. zalecające nie mieć dwóch ubrań, ani obuwia, i nie troszczyć się o przyszłość [...]. Wytrzymywał zimno i zupełne ogołocenie, tak że swe ubóstwo doprowadził do ostatecznych granic [...]. Przez długie lata chodził boso, bez obuwia, ponadto jeszcze dłużej powstrzymywał się od wina [...]. Nawet popadł w niebezpieczeństwo osłabienia i zrujnowania swego zdrowia. Tym, co na niego patrzeli, dawał tak wspaniały przykład życia filozoficznego, że porywał za sobą bardzo wielu naśladowców ${ }^{57}$.

Podobnie jak filozofia, tak samo chrześcijaństwo nie ograniczało się do czysto umysłowego ćwiczenia, ale angażowało całe życie człowieka i wymagało wyrobienia odpowiedniej postawy moralnej ${ }^{58}$. W pełni reprezentował ją, w pojęciu Euzebiusza z Cezarei, właśnie Orygenes - mistrz. W jego osobie zbiegają się rysy Sokratesa i Chrystusa. Biskup Cezarei przez nawiązanie do postaci dawnego filozofa greckiego ukazuje ewolucję pojęcia filozofii, które nabrało autonomii i rysów typowo chrześcijańskich. Chociaż wątki ewangeliczne wydają się słabiej widoczne, jednak są wzmianki o niekończących się tłumach słuchaczy ${ }^{59}$. Historyk Kościoła przypomina o prześladowaniach, jakie dotknęły Adamancjusza. Euzebiuszowi nie chodzi jednak o przypisywanie Orygenesowi cech Chrystusa, lecz o podkreślenie, iż jego życie było zgodne z najwyższą filozofią chrześcijaństwa i wiernym naśladowaniem Syna Bożego.

Sam Orygenes natomiast uważał się po prostu za przewodnika i wprowadzającego innych w tajemnice Pisma Świętego. Kluczowym pojęciem jest tutaj manuductio (gr. cheiragōgha) ${ }^{60}$, nauczyciel bowiem chrześcijański ,prowadzi za rękę” ku poznaniu Słowa Bożego. Dzieje się tak, jak w przypadku, gdy ,człowiek bez wiedzy i wykształcenia [...]. zdający sobie sprawę ze swoich braków, powierza się temu, kto w jego przekonaniu może doprowadzić go do wiedzy i cnoty [...]. Ten [zaś], któremu się powierza [...] obiecuje odjąć mu niewiedzę i wpoić wiedzę oraz doprowadzić do poprawy" ${ }^{61}$. Analogia do relacji wierzącego z egzegetą - ,pedagogiem” jest bardzo wyraźna. „Niechaj te nasze ogólne sformułowania będą wskazówką dla tych, którzy pragną [...] zrozumieć treść całej tej księgi [tj. Liczb], aby każdy znalazłszy tutaj sposobność duchowego pojmowania, również w pozostałych księgach [biblijnych] kontynuował poszukiwania albo [...] szukał wznioślejszego sensu"62.

Czasami nauczyciel - przewodnik nalega z większą mocą: „Spróbuj i ty, słuchaczu, mieć własną studnię i własne źródło ${ }^{63}$, abyś skoro zrozumiesz księgę Pism, za-

${ }^{57}$ Historia ecclesiastica VI, 3.

${ }^{58} \mathrm{~W}$ odróżnieniu od filozofii pogańskiej nauka Chrystusa była skierowana do wszystkich.

${ }^{59}$ Jest to nawiązanie do działalności Chrystusa w Kafarnaum (por. Mk 1, 21-39). Por. Historia ecclesiastica VI, 15; 30.

${ }^{60} \mathrm{Na}$ temat tego pojęcia u Orygenesa por. G. I. Gargano, La teoria di Gregorio di Nissa sul Cantico dei Cantici. Indagine su alcune indicazioni di metodo esegetico (Orientalia Christiana Analecta 216), Rzym 1981, s. 59-60.

${ }^{61}$ Philocalia 21, 14.

${ }^{62}$ Hom. in Numeros I, 3.

${ }^{63}$ Por. Hom. in Numeros XII, 1. Na temat metafory „studni” i „źródła” por. F. Cocchini, La sor- 
czął również z własnej myśli wydobywać jakiś sens zgodnie z tym, czego się nauczyłeś w Kościele, spróbuj i ty pić ze źródła swego umysłu [...]. Oczyść [go], abyś mógł kiedyś pić ze swych źródeł i czerpać [z nich] «żywą wodę»”"64. „Studnia Słowa Bożego” jest niezgłębiona, jak mądrość Boża. „Jakiż może być kres mądrości Bożej? Im dalej ktoś postąpi, tym większe napotka głębiny; im bardziej będzie dociekał, tym lepiej zrozumie, iż sprawy te są niewysłowione i niepojęte" ${ }^{65}$. Dlatego zgłębianie natchnionych pism to bardzo odpowiedzialne zadanie. $Z$ tego powodu Orygenes, jeśli wierzyć relacji Euzebiusza z Cezarei, pozwolił na spisywanie swoich nauk dopiero w starszym wieku, gdy „nabył łatwość słowa" ${ }^{\prime 6}$.

Interpretowanie Pisma Świętego to wspólna droga nauczyciela i ucznia. Poznając mądrość natchnionych ksiąg, człowiek spotyka się z wielką różnorodnością „pokarmu duchowego”. Każdemu bowiem Słowo Boże ofiaruje szczególne dobro ${ }^{67}$. Pismo Święte ukazuje, że zbawienie, jakie przychodzi przez Chrystusa, nie jest odosobnionym wydarzeniem historycznym. Poprzedzały je kolejne fakty historii zbawienia, poczynając od samego aktu stworzenia, gdy do istnienia został powołany człowiek, stworzony na obraz i podobieństwo Boga. Po upadku Adama nastapił długi ciag proroków Izraela, wielkich filozofów greckich i mądrych prawodawców, przez których Bóg przemawiał. Orygenes odnajduje przejawy Logosu i Opatrzności w całym ciagu ludzkich dziejów i zestawia fakty z dziejów greckiej myśli z mądrością natchnionych ksiag Biblii. Paideia w jego ujęciu staje się stopniowym wypełnianiem Boskiej opatrzności (pronoia) ${ }^{68}$, która ma w swej pieczy świat i rodzaj ludzki. Ta idea ma fundamentalne znaczenie dla całej teologii Orygenesa. Poprzez podkreślanie ciagłości Starego i Nowego Testamentu doktor aleksandryjski występuje przeciwko Marcjonowi, który dyskredytował historię zbawienia i pomniejszał wartość Starego Prawa, jako dzieło „mniejszego Boga” - demiurga ${ }^{69} . \mathrm{Z}$ marcjonitami przyjdzie potykać się Orygenesowi w kwestii wolnej woli człowieka ${ }^{70}$.

gente di Giacobbe (Gv 4): Funzionalità ed ermeneutica di una metafora origeniana sulle Scritture, w: L. Padovese (red.), Atti del V simposio di Efeso su S. Giovanni Apostolo (Turchia: la Chiesa e la sua storia 8), Rzym 1995, s. 139-146.

${ }^{64}$ Hom. in Genesim XII, 5.

${ }^{65}$ Hom. in Numeros XVII, 5.

${ }^{66}$ Historia ecclesiastica VI, 36.

${ }^{67}$ Orygenes stosuje trójdzielny schemat rozumienia Pisma Świętego, który przedstawia w De principiis IV, 2, 4. Por. M. Simonetti, Między dosłownościq a alegoriq. Przyczynek do historii egzegezy patrystycznej, Myśl Teologiczna 2000, nr 26, s. 79-87.

${ }^{68}$ Pojęcie tego typu wprowadzili stoicy. Odwieczne prawa natury są przejawem Boskiego Logosu, który przenika całość bytu. Por. W. Jaeger, Wczesne chrześcijaństwo i grecka paideia..., s. 81, przypis 39. Autor cytuje H. Kocha, Pronoia und Paideusis, Berlin-Leipzig 1932.

${ }^{69} \mathrm{~W}$ opinii Ireneusza z Lyonu Marcjon nie tylko dorzucał cały Stary Testament, lecz również „przekonywał swoich uczniów, że jest bardziej prawdomówny od apostołów, którzy przekazali Ewangelię" (Adversus haereses III, 3, 1). Sądził bowiem, że „Apostołowie domieszali do słów Zbawiciela przepisy Prawa. I nie tylko apostołowie, lecz także sam Pan Jezus mówił raz głosem Demiurga [...], a czasem [przez osobę] Najwyższego [...]. To jednak jest bezwstydnym bluźnierstwem wobec Stwórcy" (tamże III, 2, 1).

${ }^{70} \mathrm{~W}$ swojej polemice Orygenes rozróżnia pomiędzy marcjonitami a gnostykami. Przeciwko argumentom pierwszej grupy heretyków Aleksandryjczyk występuje w: De principiis III, 9; Philo- 


\section{Wolna wola człowieka i sposób działania Boga}

Orygenes polemizuje z determinizmem pogańskim i gnostycką ideą znoszącą wolną wolę istot rozumnych ${ }^{71}$. W całym swym dziele autor ten pozostał ,nieugiętym rzecznikiem wolnej woli człowieka"72. To niewątpliwie trafne określenie, chociaż wola dla starożytnego pisarza oznaczała coś innego niż dla współczesnego człowieka. Także i w tej kwestii aleksandryjski myśliciel starał się nadać spójność swemu szerokiemu systemowi filozoficzno-teologicznemu, niż być echem swych poprzedników ${ }^{73}$. W starożytnym chrześcijaństwie gnostycy zajęli miejsce fatalistów ${ }^{74}$, których zwalczano, ukazując kwestię pochwały i nagany, zakładających przekonanie o istnieniu wolnej woli ${ }^{75}$. Dla Ireneusza z Lyonu to właśnie wolna wola była elementem reprezentatywnym obrazu Boga w człowieku ${ }^{76}$. Klemens Aleksandryjski uważa wolność stanowienia o sobie za przywilej człowieka, udzielony mu przez Zbawcę7. To, że Orygenes pojmował człowieka jako istotę zdolną do wolnego, moralnego działania ${ }^{78}$, stanowiło główny

calia 27, 1; 12; In Exodum (fragm.) 4, 22-23. Por. J. Rius-Camps, Origenes y Marción. Caracter preferentemente antimarcionita del prefacio y del segundo ciclo del Peri Archôn, w: H. Crouzel (red.), Origeniana. Premier colloque international des études origéniennes (Montserrat, 18-21 septembre 1973) (Quaderni di «Vetera Christianorum» 12), Bari 1975, s. 297-312.

${ }^{71}$ Por. Philocalia 21, 1; 16. Por. E. Norelli, Marcione e gli gnostici sul libero arbitrio e la polemica di Origene, w: L. Perrone (red.), Il cuore indurito del Faraone. Origene e il problema del libero arbitrio (Origini 3: Studi e Testi del CISEC), Bolonia 1992, s. 1-30.

${ }^{72}$ Por. H. Crouzel, Orygenes..., s. 259.

${ }^{73}$ „Wielu wyznawców wiary Chrystusowej różni się między sobą nie tylko w poglądach na temat spraw drobnych, lecz również w zakresie problemów ważnych i zasadniczych [...], dlatego też uważam za konieczne najpierw przedstawić pewną zasadę i określoną regułę dotyczącą tej kwestii, a dopiero potem zastanowić się nad pozostałymi problemami". De principiis, praef. 2. Por. H. Crouzel, M. Simonetti, Origène. Traité des principes, t. 1-5 (SC 252; 253; 268; 269; 312), Paryż 1978; 1980; 1984; S. Kalinkowski (tłum.), W. Stanula, W. Myszor (oprac.), Orygenes. O zasadach (Pisma Starochrześcijańskich Pisarzy 23), Warszawa 1979.

${ }^{74}$ Por. Cyceron, De fato XVII, 40. Por. przede wszystkim D. Amanci, Fatalisme et liberté dans l'antiquité grecque. Recherches sur la survivance de l'argumentation morale antifataliste de Carnéade chez les philosophes grecs et les théologiem chretiens des quatre premiers siècles, Lowanium 1945 (druk anastatyczny Amsterdam 1973), s. 304, przypis 2. Ponadto por. M. E. Reesor, Fate and Possibility in Early Stoic Philosophy, Phoe 19 (1965), s. 285-297. Na temat ogólnego pojęcia przeznaczenia i opatrzności por. A. Magris, L'idea del destino nel pensiero antico, t. 1-2, Triest 1985.

${ }^{75} \mathrm{Na}$ temat pojęcia wolnej woli w starożytności klasycznej por. A. Dihle, The Theory of Will in Classical Antiquity, Berkeley-Los Angeles-Londyn 1982, s. 111-112. Natomiast jeśli chodzi o zhellenizowany judaizm por. D. S. Winston, Freedom and Determinism in Greek Philosophy and Jewish Hellenistic Wisdom, Studia Philonica 2/1973, s. 40-50; tenże, Freedom and Determinism in Philo of Alexandria, tamże 3 (1974-1975), s. 47-70.

${ }^{76}$ Por. Adversus haereses IV, 4, 3; 37, 4; 38, 4.

77 „My zaś za pośrednictwem Pisma Świętego dowiedzieliśmy się, że pełną, niczym nie skrępowaną wolność pozytywnego wyboru lub odrzucenia otrzymali ludzie od samego Pana". Stromata II, 12, 1. Por. C. Mondésert (wstęp), M. Caster (tłum. i przypisy), Clément d'Alexandrie. Les Stromates I (SC 30), Paryż 1951.

${ }^{78}$ Był to również argument Tertuliana polemizującego ze zwolennikami Marcjona; por. Adversus Marcionem II, 6, 1-8; 7, 1-5. 
filar jego systemu. Tematyka wolności wyboru została zaczerpnięta z etyki Arystotelesa. Szczególnie poruszone w Etyce nikomachejskiej zagadnienie wstępnego wyboru ten grecki filozof rozprowadził na wielu stronicach swoich pism jako problem intencji moralnej i samego zbawienia ${ }^{79}$.

Całą księgę III De principiis Orygenes poświęcił problematyce wolnej woli, zazębiając kwestie biblijne i refleksję filozoficzną ${ }^{80}$. Aleksandryjski myśliciel odrzucał twierdzenie, że Boskie dzieło byłoby doskonalsze, gdyby Bóg pozbawił swoje stworzenie tej tak ważnej cechy, jaką jest zdolność wolnego wyboru dobra ze względu na nie samo. Fakt, że Bóg respektuje wybór człowieka i nigdy go nie zniewala, to niezmienna myśl w doktrynie Adamancjusza ${ }^{81}$.

Rozważania Orygenesa dotyczące wolnej woli bazują na analizie aktu wolnego bytu i są ukierunkowane na udowodnienie, że działanie wypływa z rozumowania, ponieważ człowiek nie jest zdeterminowany przez „obrazy rzeczy” i może dać lub nie swoje przyzwolenie. Osąd nie jest niczym ograniczony ${ }^{82}$, a wolna wola jest ściśle związana $\mathrm{z}$ godnością bytu duchowego lub stworzenia cielesnego obdarzonego duszą ${ }^{83}$. Wolność warunkuje wartość aktu ludzkiego i czyni go zasługującym lub skazującym na potępienie $^{84}$. To jedna z podstawowych cech wyróżniających stworzenia rozumne. Orygenes nie unika w tej kwestii paradoksów. Tak na przykład, „dusze w naszym pojęciu są [...] niezliczone, oraz niezliczone są ich charaktery, ich odczucia, ich zamiary, dążenia, instynkty ${ }^{85}$; ich jeden, jedyny Gospodarz najlepszy zna i czas naprawy, i odpowiednie środki, i sposoby wychowywania dusz, i drogi, jakimi je prowadzi”" ${ }^{\prime 66}$.

${ }^{79}$ Temat wolnej woli stanowi treść III księgi dzieła Arystotelesa. Por. D. Gromska (tłum.), Arystoteles. Etyka nikomachejska, Warszawa 1956.

${ }^{80}$ B. Darrell Jackson, Sources of Origen's Doctrine of Freedom, Church History 35/1966, s. 16-21. Na biegunowość i konfliktowość tych zasad zwraca uwagę H. Holz, Über den Begriff des Willens und der Freiheit bei Origenes, Neue Zeitschrift für systematischeTheologie und Religionsphilosophie 12/1970, s. 63-84. Kwestię rozwija L. Perrone, La parrhêsia di Mosé: l'argomentazione di Origene nel Trattato sul libero arbitrio e il metodo della „,quaestiones et responsiones”, w: tenże (red.), Il cuore indurito del Faraone..., s. 31-64.

${ }^{81}$ W wykładzie „reguły wiary” w De principiis I, 5 Orygenens mówi o wolnej woli, w którą wyposażona jest dusza rozumna. Autor omawia całościowo artykuły wiary przyjmowane przez zwykłych chrześcijan (por. Comm. in Johannem XIII, 16, 98) i wyjaśnia ich treść (por. Comm. in I Corinthios [fragm.]). W jego koncepcji tradycja była równoznaczna z kerygmatem przekazanym przez apostołów (por. De principiis III, 1, 1). Por. J. N .D. Kelly, Poczqtki doktryny chrześcijańskiej, Warszawa 1988, s. 43.

${ }^{82}$ Por. De principiis III, 5, 4.

${ }^{83}$ Por. Comm. in Romanos. VIII, 11.

${ }^{84}$ Por. De principiis III, 1, 2-5. Fragment De principiis III, 1, 2-5 ma wiele analogii do De oratione 6, 1-2. Por. Ph. J. Van Der Eijk, Origenes'Verteidigung des Freien Willens in De oratione 6, 1-2, Vigiliae Christianae 42/1988, s. 339-351.

${ }^{85} \mathrm{Na}$ temat tej terminologii por. B. Inwood, Ethics and Human Action in Early Stoicism, Oxford 1985, s. 231-233.

${ }^{86}$ Philocalia 13 (14). Do podobnej konkluzji doprowadza wywód przytoczony tamże 27, 9 , chociaż nie używa się powyższej terminologii. 
Wolność, którą obdarzony jest rozumny człowiek, implikuje jednak pewien rodzaj niestałości. „Stworzenia [...] zostały obdarzone wolną wolą, i właśnie wolna wola pociągnęła każdą poszczególną istotę albo do rozwoju poprzez naśladowanie Boga, albo popchnęła ku upadkowi wskutek niedbałości”»7. Orygenes wyjaśnia to nieco dokładniej w jednym z wcześniejszych fragmentów dzieła $O$ zasadach:

Natury rozumne [...] są zmienne i niestałe [...]. Istnienie nie jest wieczną własnością, lecz darem Bożym [...] wszelki dar może zostać odebrany i może przepaść [...]. [Przyczyną utraty dobra] jest fakt, że poruszenia duchów nie są kierowane należycie i rozsądnie. Stwórca zezwolił stworzonym przez siebie Bytom dobrowolne i swobodne działanie, aby powstało w nich ich własne dobro [...]. Jednakże lenistwo i wstręt do wysiłku w zachowaniu dobra oraz niechęć i lekceważenie wyższych wartości dały początek odchodzeniu od tego co dobre ${ }^{88}$.

Widać tutaj w całej pełni teorię działania $\mathrm{z}$ wyboru, wykluczającego działanie ślepego przeznaczenia (fatum). W istnieniu bytu rozumnego następuje duchowy rozwój lub degradacja. Wszystko zależy od ludzkiej umiejętności rozróżniania między dobrem prawdziwym a pozornym, między prawdą a fałszem, bytem a niebytem. Już dla Platona w tym właśnie punkcie filozofia stała się paideiq - wychowaniem człowieka. Orygenes tak właśnie pojmował chrześcijaństwo, kształtujące oblicze duszy w jej wolnym i niezależnym działaniu.

Według kosmologii Orygenesa, wszystkie stworzenia podlegają zmianom i ruchowi ${ }^{89}$. W sposób dosyć zawiły Adamancjusz wyjaśnia różnorodność bytów rozumnych, cielesnych i bezcielesnych ${ }^{90} . \mathrm{Z}$ ich hierarchii wywodzi istnienie wolnej woli, a różnorodność natur opiera na różnicy opcji. „Stwórca wszechrzeczy zastosował pewne zarodki i przyczyny różnorodności, aby stworzyć różnorodny i zmienny świat, stosownie do różnorodnych umysłów" "91. Kieruje ostrze swej polemiki przeciwko tym, którzy potępiają cielesność i widzą w niej przyczynę zła. Dla Aleksandryjczyka to wolna wola przyczyniła się do powstania zła ${ }^{92}$. To właśnie jego rozplenienie się blokuje proces reedukacji i nawrócenia. „Niektórzy ulegli tak wielkiej niegodziwości i złu, że nie tylko uznano ich za niegodnych nauki i pouczenia [...], lecz są wrogami i nieprzyjaciółmi tych, którzy otrzymują naukę i wykształcenie" ${ }^{\prime 3}$.

Dusze postrzegają rzeczywistości zmysłowe, co wskazuje na ich pokrewieństwo. Nawyki u Orygenesa nie odgrywają w tym procesie żadnej roli. Jednak to one wła-

${ }^{87}$ De principiis II, 9, 6. Na temat upadku istot rozumnych por. J. W. Trigg, Origen: The Bible and Philosophy in the Third-century Church, Atlanta 1983, s. 109.

${ }^{88}$ De principiis II, 9, 2.

${ }^{89}$ Jest to tematyka typowo stoicka. Por. np. H. von Arnim, Stoicorum veterum fragmenta, t. 2, Stuttgart 1964, s. 174. Pojawia się ona również u Filona Aleksandryjskiego. Por. Leges allegoriae II, 22; De rerum divinarum heres sit 137.

${ }^{90}$ Por. De principiis I, 8, 1; Hom. in Genesim XV, 5; Contra Celsum V, 29.

${ }^{91}$ De principiis II, 9, 2.

${ }^{92}$ Por. Contra Celsum IV, 65.

${ }^{93}$ De principiis I, 6, 3 . 
śnie scalają wrażenia i identyfikują przedmiot postrzegania z tym, co jest różne od podmiotu poznającego. Aleksandryjczyk opiera się na samorzutnym wrażeniu duchowym i charakterze intuicyjnym poznania ${ }^{94}$. Zwraca jednak uwagę, że ,zewnętrzne okoliczności nie zależą od naszej woli; od nas jednakże zależy, jak wykorzystamy te okoliczności - dobrze czy źle, bo tkwiący w nas rozum osądza i rozstrzyga, w jaki sposób należy z nich korzystać" ${ }^{95}$. To racjonalny osąd pozwala podejmować decyzje i uniezależniać się od wpływów otoczenia. Orygenes wyjaśnia bowiem, że „przy określonych możliwych posunięciach przed trybunałem naszego serca i jak gdyby w obecności sędziego rozpatruje się rzecz z przeciwstawnych punktów widzenia, ażeby dopiero po wyłożeniu motywów rozum wydał wyrok w sprawie działania"96. Aleksandryjczyk uznaje więc wolność sytuacyjną ${ }^{97}$, zbieżną w pewnym stopniu z Sartrowskim „paradoksem wolności”"98.

Wpływ Boga to dla Aleksandryjczyka klucz do zrozumienia mechanizmu wolnej woli. Bóg obdarza rozumne istoty swoimi darami, które stanowią Jego nierozłączne przymioty i strzeże, aby ich wola nie zwyrodniała przez upadek ${ }^{99}$. Dusze powinny nieprzerwanie postępować w dobrym i doskonalić się, także w wieczności.

Dzięki odnowieniu ciągłego oddziaływania na nas Ojca, Syna i Ducha Świętego na poszczególnych stopniach doskonałości możemy niekiedy dostrzec świętą i błogosławioną drogę; jeśli po wielu trudach możemy do niej dotrzeć, winniśmy wytrwać na tej drodze, ażeby nigdy nie ogarnął nas przesyt tego dobra; przeciwnie, im więcej otrzymujemy z tego szczęścia, tym bardziej powinno się w nas rozszerzać i powiększać jego pragnienie, w miarę jak coraz goręcej i gorliwiej przyjmujemy albo pojmujemy Ojca, Syna i Ducha Świętego ${ }^{100}$.

Aleksandryjczyk nie dostrzega możliwości, aby Bóg, który stworzył wszystkie byty rozumne jako równe co do godności i podstawowych cech, pozostawił je samym sobie, gdy odstapią od swej pierwotnej doskonałości.

${ }^{94}$ Por. H. Crouzel, Orygenes..., s. 174.

${ }^{95}$ De principiis III, 1, 5.

${ }^{96}$ De principiis III, 1, 4.

97 „To, co działa na nas z zewnątrz, jest niezależne od naszej woli - nie możemy sprawić, żeby nie oddziaływało; jednak ocena i decyzja, jak mamy zużytkować to, co na nas oddziaływa, jest już tylko przedmiotem pracy owego tkwiącego w nas rozumu, to znaczy naszego sądu; gdy oddziałują na nas zewnętrzne impulsy, opieramy się na osądzie tego rozumu w tym, co sam rozum zaaprobuje, bo jego decyzja kieruje naszymi naturalnymi poczynaniami w kierunku dobra lub zła". De principiis III, 1,3 .

98 „Wolność istnieje tylko w [określonej] sytuacji, a sytuacja powstaje tylko dzięki wolności”. J. P. Sartre, Being and Nothingness, w: R. C. Solomon (red.), Phenomenology and Existentialism, Nowy Jork 1972, s. 465.

${ }^{99}$ Orygenes odwołuje się do określenia katabolê, oznaczającego w Nowym Testamencie „,założenie świata" (por. Mt 13; 35; Łk 11, 50; J 17, 24; Ef 1, 4; Hbr 4, 3; 1 P1, 20; Ap 13, 8), lecz w przypadku stworzenia rzeczywistości materialnej chodzi o „ciążenie ku dołowi”. Por. De principiis II, 8, 4; III, 5, 4-5.

${ }^{100}$ De principiis I, 3, 8. Por. J. Daniélou, Messaggio evangelico e cultura ellenistica, Bolonia 1975, s. 448 . 
W kategoriach paidei Aleksandryjczyk analizuje problem cierpienia na świecie i kar. Uważa, że należy pojmować je jako „przykrości, które nauczyciele, rodzice i wychowawcy sprawiają wychowankom albo lekarze pacjentom Mówimy, że rodzice wyrządzają zło dzieciom, tak samo jak nauczyciele, wychowawcy i lekarze [...]. Nie zasługują na naganę ci, którzy stosują chłostę [...]. Bóg zsyła jakieś zło po to, ażeby nawrócić i uleczyć tych, którzy wymagają takich cierpień" ${ }^{101}$. Obok konieczności bolesnej kary Orygenes wprowadza element decyzji i wolnej woli, co zgadza się zresztą z ogólnym kontekstem omawianej kwestii ${ }^{102}$. Według optyki chrześcijańskiej, zbawienie człowieka zależy od osobistego wyboru, który stanowi nieodzowny warunek wszelkiego postępu w cnocie. Przy tej okazji autor De principiis nawiązuje do standardowej koncepcji platońskiej, według której brak racjonalności (logos) oznacza zniewolenie ${ }^{103}$. Odrzucając rozumne działanie przestaje się być wolnym i popada się $\mathrm{w}$ niewolę ignorancji, nawet nie zdając sobie $\mathrm{z}$ tego sprawy. Upadek związany jest więc najściślej z ignorancją, której nie utożsamia się z brakami w formacji intelektualnej i duchowej, lecz z faktem ospałości, bierności i oddalenia od Boga ${ }^{104}$. Nie ulega wątpliwości, że

stworzenie rozumne [...] potrafi oceniać i rozróżniać naturalne działania, może jedne z nich potępiać i odrzucać, a inne akceptować i przyjmować, i dzięki ocenie rozumu poczynania ludzkie mogą się zwracać ku chwalebnemu życiu. Wynika stąd wniosek, że istota rozumu tkwiącego w człowieku ma w sobie zdolność rozróżniania dobra i zła, a gdy dokona tego rozróżnienia, posiada możliwość wyboru tego, co uznała za słuszne: wybierając to, co dobre, zasługuje na pochwałę, idąc zaś za tym, co szpetne i złe, słusznie zostanie uznana za godną potępienia ${ }^{105}$.

${ }^{101}$ Contra Celsum VI, 56.

102 Powyższe kwestie zostają rozwinięte w: De principiis III, 1, 8-9; Comm. in Romanos VIII, 11-13; IX, 2; Philocalia 21-27. Komentarz do Rz w thum. wł. w: F. Cocchini, Commento alla lettera ai Romani, t. 1 („Ascolta Israele!”. Commenti alle Scritture delle tradizioni ebraica e cristiana 2), Casale Monferrato 1985. Dyskusję nad problemem wolności u Orygenesa podejmują: M. Simonetti, I Principi di Origene, Turyn 1968, s. 364, przypis 1; Junod, Origène. Philocalie 21-27: Sur le libre arbitre, s. 19-20; R. Calonne, Le libre arbitre selon le Traité des principes d'Origène, Boulletin de Littérature Ecclésiastique 89/1988, s. 243-262; B. D. Jackson, Sources of Origen's doctrine of freedom, Church History 35/1966, s. 13-23; H. Holz, Über den Begriff des Willens und der Freiheit bei Origenes, Neue Zeitschrift für Theologie und Religionsphilosophie 12/1970, s. 63-84. Szerszy kontekst przedstawiają D. Amand, Fatalisme et liberté dans l'antiquité grecque. Recherches sur la survivance de l'argumentation morale antifataliste de Carnéade chez les philosophes grecs et lei théologiens chrétiem des quatre premiers siècles, Lowanium 1945 (druk anastatyczny, Amsterdam 1973) i U. Berner, Untersuchungen zur Verwendung des Synkretismus-Begriffes..., s. 153.

${ }^{103}$ Por. De principiis III, 5, 4. Por. Platon, Republica 533 c-d; Plotyn, Enneady I, 3, 5-6.

${ }^{104}$ Nie dzieje się to więc z powodu wrodzonej skłonności do zła. Por. De principiis I, 4, 1. Alternatywna interpretacja w: L. Hennessey, The Place of Saints and Sinners After Death, w: C. Kannengiesser, W. L. Petersen (red.), Origen of Alexandria: His World and His Legacy, Indianapolis 1988, s. 310, przypis 46.

${ }^{105}$ De principiis III, 1, 3. 
Tylko Boże działanie w postaci paidei może rozproszyć mroki niewiedzy i przywrócić racjonalność decyzji. Dla Orygenesa poznanie (gnosis) to nie owoc natchnionej ekstazy czy jednorazowego aktu kontemplacji, lecz należy je pojmować w sensie dynamicznym: wchodzenie w Boży zamysł i jego implikacje praktyczne ${ }^{106}$. Doktor aleksandryjski wskazuje przy tym na przykład tych, którzy „zachęceni ku lepszemu słowem nauki i wiedzy przeszli wielką przemianę [...] [i] stali się wstrzemięźliwi i czyści"107. Prawdziwa wolność polega na właściwym postępowaniu, ciagłym wzroście duchowym i doskonaleniu się.

Czuwanie Boga nad człowiekiem to pronoia $^{108}$ utożsamiana z opatrznością. Jest to „pedagogiczna moc” prowadząca po ścieżkach wolności. W wieloaspektowym systemie teologicznym Orygenesa spotykają się w ten sposób miłość i sprawiedliwość, które tylko z pozoru wydają się wykluczać. Te obydwa aspekty dopełniają się w zbawczej paidei Boga ${ }^{109}$. Dla Orygenesa opatrzność nie jest nakazująca, lecz wychowująca. Prawdziwa crux interpretatorum Adamancjusza to nie tyle paradoksy czy łączenie przeciwieństw, lecz jego przekonanie, że sprawiedliwość ma znaczenie pouczające i korygujące, nie zaś karzące. Mimo faktu, że teolog aleksandryjski broni prawdy o Sądzie Ostatecznym, jednak staje się on wyłącznie aktem o znaczeniu pouczającym ${ }^{110}$. Tym samym kwestia sprawiedliwości $(\text { dikê })^{111}$ zostaje zepchnięta na margines i podporządkowana paidei.

Działanie wolnej woli nie może w żaden sposób doprowadzić do ostatecznego zniszczenia i potępienia. Dlatego Orygenes mówi nawet o dopełnieniu się liczby wybranych $^{112}$, postępujących według „wieczystej Ewangelii”, do której nic nie zostanie dodane ${ }^{113}$. Jest to jeden $\mathrm{z}$ aspektów apokatastazy ${ }^{114}$, na końcu bowiem czasów nastapi odnowienie wszystkiego w Bogu i wszystko powróci do swego duchowego i chwalebnego stanu. Ukoronowaniem istnienia wszechświata jest powszechna odnowa.

[Bóg] przywołuje stworzenia do jednolitej harmonii w uczynkach i chęciach [...] Wszystkie poszczególne duchy lub dusze - czy jak tam nazwiemy istoty rozumne - nie są zmuszane do działania wbrew wolnej woli i wbrew chęciom swojego umysłu; w przeciwnym wypadku można by sądzić, że zabrano im wolną wolę, a to przecież zmieniłoby jakość ich

${ }^{106}$ Por. szeroką analizę w: J. Daniélou, Messaggio evangelico e cultura ellenistica..., s. 541-582.

${ }^{107}$ De principiis III, 1, 5.

${ }^{108}$ Por. De oratione 5, 2-3; wyd. krytyczne w: P. Koetschau (wyd.), Origenes Werke, t. 1; GCS 3 [= Die Griechlischen Christlichen Schriftseller]), Leipzig 1899.

${ }^{109}$ Bóg przyciaga do siebie przez miłość. Por. Commentarius in Rom. V, 10, 15.

${ }^{110}$ Por. M. C. Steenberg, Origen and the Final Restoration: a Question of Heresy, wersja elektroniczna wg: www.monachos.net.

${ }^{111}$ Por. defnicję dikê w: G. Kittel (wyd.), G. W. Bromiley (thum. ang.), Theological Dictionary of the New Testament, t. 2, Grand Rapids 1964, s. 180.

112 Por. A. Monaci, Apocalisse ed escatologia nell'opera di Origene, Augustinianum 18/1978, s. 148.

${ }^{113}$ Por. De principiis III, 6; IV, 3.

${ }^{114}$ E. Moore, Origen of Alexandria and apokatastasis: Some Notes on the Development of a Noble Notion, Quodlibet Journal 5/1/2003/, wersja elektroniczna wg: www.quodlibet.net. 
natury; różnorodne ich poczynania w sposób stosowny i korzystny zostały uzgodnione $\mathrm{z}$ harmonią jednolitego świata ${ }^{115}$.

Ma się tu do czynienia ze stoickim podkreśleniem jedności i spójności świata ${ }^{116}$, co służy naszemu autorowi do przywołania jedności woli w zharmonizowanej całości stworzenia.

\section{„Habitus”: właściwości i formowanie}

Gnostykom, którzy dominowali w środowisku aleksandryjskim w III wieku, Orygenes przeciwstawia interpretację formacji i kształtowania cnót w duchu wiary i tradycji Kościoła. Według błędnowierców, formacja była zarezerwowana dla „doskonałych", a dla znajdujących się na pośrednim szczeblu rozwoju duchowego konieczne było przejście ze zniewolenia ku wolności ${ }^{117}$. „,Rozumne przyzwyczajenia”"118 i ,„przyzwyczajenia zgodne z naturą"119 pojawiają się u Klemensa z Aleksandrii. Jednakże pojęcie hexis utożsamiane jest przez niego z działaniem zgodnym z Logosem ${ }^{120}$. Ponadto autor Pedagoga przyswoił aleksandryjskiemu środowisku teologicznemu podstawowe rozróżnienie stosowane przez stoików pomiędzy określeniami ,habitus praktyczny" i ,teoretyczny" "121. Orygenes przejmie od Klemensa związek hexis z cnotami w znaczeniu stoickim ${ }^{122}$. Nadaje to doktrynie moralnej Adamancjusza charakter ściślej intelektualny, który objawi swój wpływ w późniejszej patrystyce greckiej ${ }^{123}$. Obok nurtu stoickiego pojęcie nawyków ukształtowała także refleksja Filona z Aleksandrii ${ }^{124}$.

Nie należy jednak zapominać o podstawowym znaczeniu, jakie dla Orygenesa, jednego z największych egzegetów Kościoła, mają kategorie biblijne. Posiłkuje się on formułami filozoficznymi w kontekście egzegezy i w rozwiązywaniu problemów interpretacyjnych natchnionych tekstów. Biblijne sentencje mądrościowe rozpatry-

${ }^{115}$ De principiis II, $1,2$.

${ }^{116}$ Por. Stoicorum veterum fragmenta..., t. 2, s. 441, 447, 548-552. Por. także Contra Celsum IV, 54.

${ }^{117}$ Por. Exerpta ex Theodoto I, 56, 4-57.

${ }_{118}$ Por. H. von Arnim, Stoicorum veterum fragmenta..., t. 3, s. 219, 12; 252, 38.

${ }^{119}$ Myśl wyrażona jest w różny sposób. Por. H. von Arnim, Stoicorum veterum fragmenta..., t. 3, s. 3,$30 ; 4,12 ; 5,17$.

${ }^{120}$ Por. Paedagogus III, 55. Por. H. I. Marrou, M. Harl, C. Mondésert, C. Matray (wyd.), Clement d'Alexandrie. Le pédagogue, t. 1-3 (SC 70; 108; 158), Paryż 1960; 1965; 1970.

${ }^{121}$ Por. np. Stromata IV, 39.

${ }^{122}$ Klemens Aleksandryjski mówi o wiedzy (por. Stromata II, 9; 76 i 77), poznaniu (por. Stromata V, 83; VI, 74) i niewzruszoności (por. Stromata IV, 138; VII, 7;10).

${ }^{123}$ Por. doskonałe studium Ph. G. Renczes, Agir de Dieu et liberté de l'homme. Recherches sur l'anthropologie théologique de saint Maxime le Confesseur (Théologie et sciences religieuses. Cogitatio fidei 229), Paryż 2003.

${ }^{124}$ Jak się wydaje, także jego doktryna przesiąknięta jest elementami stoicyzmu. Por. np. Leges allegoriae I, 57; II, 36-37; III, 144. 
wane są przez pryzmat nauk stoików, natomiast analiza kwestii ontologicznych bazuje nie tylko na Platonie, lecz na wielkiej alegorii Filona. Prymat Pisma Świętego w refleksji Orygenesa wiąże się z przekonaniem, że stanowi ono niezmierzony skarb i jest objawieniem się Logosu. Stąd też wszechogarniająca biblijność jego refleksji. Pismo Święte ma dla każdego odpowiedni ,pokarm” zaspokajający jego potrzeby. Na tym polega nieskończone bogactwo Bożej mądrości, która tylko w minimalnej części staje się udziałem pojedynczego człowieka ${ }^{125}$. Stosunek czytelnika do natchnionych tekstów nigdy nie jest oderwany lub statyczny, ale w najwyższym stopniu dynamiczny. Poznanie Słowa prawdy kształtuje człowieka i pozwala mu na wyrobienie właściwej postawy (habitus). Charakter „misteryjny” i „symboliczny” Biblii nie wszystkim się objawia.

Nawet najprostsi wierni uznają ${ }^{126}$, iż za pośrednictwem Pisma Świętego otrzymujemy jakieś tajemnicze wskazania [...]. Jednakże czy to dlatego, że ludzie za mało starania przykładają do ćwiczenia talentu, czy też dlatego, że zanim się czegoś naucza, sądza, że wszystko już wiedzą, nigdy nie dochodzą do początków wiedzy. Jeśli jednak nie zabraknie staranności i nauczyciela, jeśli problemy te będą badane tak jak sprawy Boskie, a nie ludzkie, to znaczy z pobożnością i czcią religijną, jeśli się będzie miało nadzieję, iż z pomocą Boga-Objawiciela zostanie to odkryte w odniesieniu do wielu zagadnieńn ${ }^{127}$.

Kończąc księgę V Komentarza do Ewangelii Jana Aleksandryjczyk daje poruszające świadectwo poczucia swej ograniczoności wobec wielkich tajemnic Biblii i broni „tych, którzy potrafią mówić i pisać. Bronię też samego siebie, bo zbyt pochopnie wziąłem się do dyktowania swych myśli nie posiadając takiej wiedzy (habitus), jaką powinien mieć człowiek, którego Bóg uznał za godnego, aby stał się «sługą Nowego Przymierza, Przymierza nie litery, lecz Ducha» (por. 2 Kor 3, 6)"'128. Cała formacja intelektualna i moralna często nie wystarczy, aby być kwalifikowanym świadkiem i przekazicielem Bożych tajemnic.

W kontekście polemicznym Contra Celsum Orygenes w sposób jeszcze bardziej zdecydowany zabiera głos w tej kwestii:

${ }^{125}$ Orygenes, podobnie jak inni Aleksandryjczycy, nawiązuje do „prawideł alegorii”. Adamancjusz określa mianem „alegorii” operację egzegetyczną, dzięki której tekst wyraża inne treści, niż mogłoby to sugerować jego dosłowne brzmienie. Tym sposobem nasz Aleksandryjczyk docieka „wyższego i duchowego sensu”, lecz z drugiej strony nadaje spekulacji tego typu ściśle określone granice. Wyznacza je „reguła wiary” Kościoła. Por. B. De Margerie, Introduzione alla storia dell' esegesi. Padri greci e orientali, t. 1, Rzym 1983, s. 123.

${ }^{126}$ Orygenes nawiązuje także w innych kontekstach do prawd przyjmowanych przez zwykłych chrześcijan i do ich treści. Por. Comm. in Johannem XIII, 16, 98. Por. C. Blanc (wyd.), Origène. Commentaire sur Saint Jean, t. 1-4 (SC 120; 157; 222; 290), Paryż 1966; 1970; 1975; 1982; S. Kalinkowski (tłum.), oprac. W. Stanula, W. Myszor, Orygenes. Komentarz do Ewangelii św. Jana (Pisma Starochrześcijańskich Pisarzy 28), Warszawa 1981.

${ }^{127}$ De principiis IV, 2, 2.

${ }^{128}$ Comm. in Johannem V, 8. 
Czynimy wszystko, aby nasze zgromadzenie składało się z ludzi roztropnych, mamy odwagę wyjawiać nasze wielkie boskie tajemnice na zgromadzeniach publicznych wobec mądrych słuchaczy, najgłębsze zaś tajemnice ukrywamy, gdy sądzimy, że słuchacze są naiwni i potrzebują nauki [...]. Niektóre prawdy są pokarmem duszy, która poczyniła postępy ku doskonałości, a inne można porównać z mlecznym pokarmem dzieci [...]. Każdy bowiem, kto pije tylko mleko, nieświadom jest sprawiedliwości, ponieważ jest niemowlęciem. Stały pokarm jest właściwy dla dorosłych, którzy przez ćwiczenie mają władze umysłowe udoskonalone do rozróżniania dobra i zła (Hb 5, 12-14) [...]. Czy wyjawiono by boskie i wspaniałe tajemnice nieletnim, tłumowi niewolników i głupców, aby się popisywać przed nimi? [...] Pragniemy wszystkich nauczać Słowa Bożego. Młodzieńcom więc udzielamy zachęty, a niewolnikom wskazujemy, w jaki sposób przyjąwszy wolnego ducha mogą stać się szlachetni przez religię. Nasi nauczyciele doktryny chrześcijańskiej [...] stwierdzają wyraźnie, że należy naprawiać ducha niemądrych, aby porzuciwszy, jeśli to możliwe, niewiedzę starali się osiągnąć mądrość ${ }^{129}$.

Orygenes podkreśla, że przekaz religijny łączy się z ,nakazem tajemnicy” ( $d i$ sciplina arcani $)^{130}$, dzięki czemu zostaje zachowany dystans wobec nieostrożnego ujawniania depozytu wiary. Temat pokarmu porusza zagadnienie pedagogiki Słowa, które jest wyłącznym pożywieniem duszy, lecz ten sam pokarm nie wszystkim odpowiada, dlatego Logos przybiera różne postacie i formy, aby dostosować się do indywidualnych potrzeb ${ }^{131}$.

Komentując J 4, 34 ${ }^{132}$, Orygenes zadaje sobie pytanie o sens tej wypowiedzi Chrystusa: „Czy więc dzieło nie zostało wykończone w akcie stworzenia, a Zbawca zakończył to, co było niedokończone i co zostało stworzone jako niedoskonałe?"133. Taka zasada kwestionuje dobro obecne w stworzeniu i władztwo Boga-Stworzyciela. Adamancjusz stara się sformułować odpowiedź, która bierze pod uwagę dzieło zbawcze czyli misję Chrystusa, który przyszedł, aby uwolnić ludzkość od skutków grzechu. „Istota, która była doskonała, w jakiś sposób przez nieposłuszeństwo utraciła tę doskonałość [...]. Dlatego został zesłany Zbawiciel [...] [Także po to], żeby każdy udoskonalony człowiek korzystał obficie ze stałego pokarmu, obcując z Mądrością"134. Stałą praktyką chrześcijanina winien być kontakt ze słowem Bożej mądrości.

Aspekt soteriologiczny nie powinien usuwać w cień faktu, że na rozważania Orygenesa dotyczące hexis wpłynęła refleksja Filona Aleksandryjskiego. Pisarz aleksandryjski sięga do określenia pragmatycznego, preferowanego przez Arystotelesa i stoików. Pozwalało to na stworzenie analogii pomiędzy cnotami a złymi przyzwy-

${ }^{129}$ Contra Celsum III, 52-54. Inne przykłady: tamże VI, 13, De oratione 27, 5.

${ }^{130}$ Por. V. Recchi, Arcano (disciplina dell'), w: A. Di Berardino (red.), Dizionario patristico e di antichità cristiane, t. 1, Casale Monferrato-Genua 1983-1988, kol. 316.

${ }^{131}$ Por. H. Crouzel, Orygenes..., s. 170.

132 „Moim pokarmem jest wypełnić wolę Tego, który Mnie posłał, i wykonać Jego dzieło" (dosłownie: ,doprowadzić do doskonałości”).

${ }^{133}$ Comm. in Johannem XIII, 238.

${ }^{134}$ Refleksję Orygenesa kończy cytat Hbr 5, 14; Comm. in Johannem XIII, 241. 
czajeniami ${ }^{135}$. Nawyki w zależności od ich charakteru tworzą cnoty (dobre) lub nałogi (złe nawyki). Ten ambiwalentny aspekt pozwolił w mentalności stoickiej na odnośnik do hexis jako czynnika formującego osobę i kształtującego jej decyzje. Cnota jest pojęta jako „sztuka” otwarta na tych, którzy ją zdobyli.

Jeśli ktoś jest sprawiedliwy, to dąży do sprawiedliwości, jeśli zaś ktoś dąży do sprawiedliwości, wcale nie musi być sprawiedliwy. Zrozumiesz to, jeśli zastanowisz się nad zdaniem: „Sprawiedliwie dąż do sprawiedliwości” (Pwt 16, 20) ${ }^{136}$, bo nie bez głębszej myśli wyraz ,sprawiedliwie” umieszczono przed zwrotem „dąż do sprawiedliwości” [...]. Można więc dążyć do sprawiedliwości w sposób niesprawiedliwy, ci więc, którzy spełniają dobry w swej istocie uczynek po to, żeby zyskać poklask u ludzi, uczynili wprawdzie coś sprawiedliwego, jednakże nie dlatego, że nawykli (habitus) do sprawiedliwości, lecz dla próżnej chwały ${ }^{137}$.

Habitus - hexis określa zdolność do zrozumienia Słowa Bożego i odznacza się silnym zabarwieniem osobistym i indywidualnym. Dlatego wyrabianie nawyków stało się zasadą egzegezy moralnej, która nie redukowała się do wskazań teoretycznych ${ }^{138}$, lecz szła w parze z życiem zgodnym z zasadami ewangelicznymi, objawiającymi się przez praktykowanie cnót. „Istnieją różne jakby formy Słowa ${ }^{139}$, w których objawia się Ono tym wszystkim, którzy przyjmują Jego naukę, i zasiada w każdym z nich w zależności od tego, jakie poczynili postępy, czy są bliscy cnoty, czy ją już osiagnęli ${ }^{140}$. W sferze alegorii moralnej nawyki oznaczają „osiaganie cnoty” oraz "ugruntowanie” w niej ${ }^{141}$. Zapewnia to oglądanie „boskiej postaci Słowa”, a ci którzy osiągnęli ten stan na podobieństwo Piotra stanowią ,skałę, na której Słowo wzniosło budowlę Kościoła; [to ci], którzy osiagnęli taką postać (habitus), że ich nie przemoże żadna brama piekielna”"142. Ci, którzy osiagnęli doskonałość i „przez ćwiczenie mają władze umysłu udoskonalone do rozróżniania dobra i zła” (Hbr 5, 14), stają się „doświadczonymi wymieniaczami pieniędzy" "143. Ludzie mający większą wiedzę i okrzepli w Bożej nauce „zawsze nad sobą panują i pamiętają o swych dawnych przemyśleniach i otrzymanych naukach, zasłaniając się tarczą wiedzy, odtrącają i odrzucają wszelką podnietę oraz sprzeciwem wrodzonego rozumu odpędzają od siebie wrogie pożądliwości"144.

${ }^{135}$ Por. Klemens Aleksandryjski, Stromata II, 133; VII, 66.

${ }^{136} \mathrm{Wg}$ Biblii Tysiaclecia: „Dąż wyłącznie do sprawiedliwości”.

${ }^{137}$ Comm. in Johannem XXVIII, 101-102.

${ }^{138}$ Już Filon z Aleksandrii sugerował egzegezę moralno-psychologiczną wielu perykop biblijnych. Por. De Abrahamo 99; Leges allegoriae II, 101.

${ }^{139}$ Por. Contra Celsum II, 64; VI, 68; 77.

${ }^{140}$ Contra Celsum IV, 16.

${ }^{141}$ Tekst oryginalny sugeruje, że chodzi o „ugruntowanie (w cnocie)”. Por. SC 136, s. 220.

${ }^{142}$ Contra Celsum VI, 77.

${ }^{143}$ Chodzi tu o agrafon cytowany przez Orygenesa w Comm. in Johannem XIX, 7, 44. Aleksandryjczyk przypisuje pierwszą część tego zdania Chrystusowi, a drugą Pawłowi. Inni pisarze cytują ten agrafon w całości jako słowa Zbawiciela. Por. M. Starowieyski (red.), Apokryfy Nowego Testamentu, I: Ewangelie apokryficzne, t. 1, Lublin 1986, s. 112.

${ }^{144}$ De principiis III, $1,4$. 
Postępowanie Boga jest porównywane do zachowania się wielkiego dobroczyńcy, stosującego całą gamę zachęt i karr ${ }^{145}$, aby uzmysłowić obecność Jego darów. Tak na przykład droga do wiary i nawrócenia biegnie wśród „strasznych chorób i przykrych słabości”'146. Na pewnym etapie formacji moralnej najskuteczniejszymi środkami leczniczymi, zdaniem Orygenesa, są próby, nierzadko aplikowane ze zdwojoną siłą ${ }^{147}$, i pozorna nieobecność Boga ${ }^{148}$. Aleksandryjczyk zauważa, że przez odstąpienie od zła wykorzystuje się należycie daną człowiekowi inteligencję ${ }^{149}$.

Orygenes wskazuje na funkcję Boskiego Logosu w formacji moralnej człowieka, przypominając, że potrzeba zarówno lekarza, aby odzyskać zdrowie, jak również nauczyciela, który pokieruje życiem danej osoby ${ }^{150}$. Orygenes twierdzi na przykład, że podobnie, jak lekarze stosują różne środki leczenia, „tak samo [również] Słowo Boże w różny sposób przemawia do ludzi, zależnie od ich sytuacji, i nie rozdaje na oślep tajemnic swojej mądrości”"151. Myśl o znaczeniu leczniczym Słowa znana była tradycji greckiej począwszy od Platona, a obecność tej tematyki u Filona Aleksandryjskiego i Orygenesa została już wielokrotnie podkreślona ${ }^{152}$. Nie należy się temu dziwić, gdyż wychowanie, wykształcenie i kary były dla Greka epoki hellenistycznej pojęciami związanymi niemal nierozłącznie. Dla naszego autora to przejaw Bożej paidei, stosowanej wobec uparcie trwających w $\mathrm{złym}^{153}$. „Cierpienia i kary, jakie Bóg nakłada na grzeszników, są lekarstwami powodującymi nawrócenie. W tej bowiem myśli roztropni chrześcijanie kierują prostaczkami niczym rodzice małymi dziećmi”"154. Aleksandryjczyk rozróżnia terapeutyczne działanie Boga i kroki podejmowane przez „doskonalszych” chrześcijan wobec ich braci. Przechodzenie na wyższy poziom moralny uważano za wynik „leczenia namiętności”. Orygenes przypominał, że tak po-

${ }^{145}$ Wartość terapeutyczna kar została podkreślona przez Orygenesa w komentarzu In Jeremiam.

${ }^{146}$ Comm. in Johannem VI, 58.

147 „W takim stanie rzeczy nie ulega dla nikogo wątpliwości, że podwojeniu ulega kara i powiększa się zło, skoro nie tylko powtarzają się grzechy uznane za odpuszczone, ale splamieniu ulega przybytek cnoty, jeżeli depczą go podstępne i skalane umysły, pełne zła ukrywającego się w ich wnętrzu". De principiis III,17.

${ }^{148}$ De principiis III, 1, 12.

${ }^{149}$ Por. Comm. in Johannem II, 8.

${ }^{150} \mathrm{O}$ tym, że chorzy potrzebują lekarza, jest mowa m.in. w: Contra Celsum III, 62; III, 74; In Ps. 67, 3 .

${ }^{151}$ In Ezechielem III, 8. Udowadnia to sam tekst prorocki: „[Bóg] mówi więc: «Ja mu odpowiem stosownie do tego, czym zaprzątnięta jest jego myśl», po to mianowicie, żeby uleczyć to, co zaprząta myśl jego, aby «nie powodował upadku domu Izraela» (Ez 14,5) [...] Kto postępuje tak «wedle serca, które odstapiło od Boga, czyni to w myślach swoich». Dlatego otrzymują odpowiedzi stosownie do tego, czym zaprzątnięte jest ich serce; rzecze [Pan]: «Powiedz domowi Izraela: Tak mówi Pan Adonai: Nawróćcie się i odstapcie od waszych pragnień» (Ez 14,6)". Tamże.

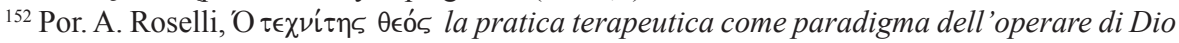
in Phil. 27 e PA III 1, w: L. Perrone (red.), Il cuore indurito del Faraone..., s. 68, przypis 12.

${ }^{153}$ Por. G. Q. Reijners. The Terminology of the Holy Cross in Early Christian Literature, Nijmegen 1965, s. 114. Orygenes stosuje tę myśl w Contra Celsum VI, 56.

${ }^{154}$ Contra Celsum III, 75. U Klemensa termin paideia thumaczony jest bardzo podobnie; por. Stromata IV, 154, 1-2. 
stępował Chryzyp usiłujący „leczyć ludzi owładniętych namiętnościami za pomocą nauk różnych szkół filozoficznych"155.

Znaczące jest porównywanie sposobu działania lekarzy i Stwórcy (,jak lekarze... tak samo Bóg”) ${ }^{156}$. Nawet pewnym demonom (,niczym katom”)

Bóg pozwala działać dla nawrócenia ludzi pogrążonych w morzu występku, albo dla ćwiczenie istot rozumnych; chodzi o to, aby ci, którzy wśród nieszczęść zachowuja pobożność i nie upadają moralnie, okazali się doskonałymi wobec widzialnych i niewidzialnych świadków, bo ci przedtem nie widzieli ich wewnętrznego nastawienia z drugiej zaś strony - aby ci, którzy postępują inaczej i ukrywają dowody swego występku - skoro okoliczności związane z próbą ujawnią, jakimi oni są naprawdę - sami mieli tego świadomość i aby, że tak powiem, tamci widzowie ich dostrzegli ${ }^{157}$.

W ten plastyczny sposób Orygenes przybliżał chrześcijanom ich moralne obowiązki. Walka ze złem, grzechem i wadami była koniecznością, gdyż chrzest wprawdzie gładzi grzechy, ale zwalczanie wad i unikanie grzechu należy do człowieka. Jest to nieustanna „walka duchowa” ${ }^{158}$.

\section{Zakończenie}

Paideia jako proces wychowawczy trwający w określonym przedziale czasowym ludzkiej egzystencji to żywy przedmiot zainteresowania starożytnego chrześcijaństwa. Pisarze starochrześcijańscy poruszali kwestie procesu formacji intelektualnej, mającej na celu zdobycie wiedzy i ogólnej sprawności umysłowej oraz zwracali uwagę na znaczenie wychowania moralnego, a wraz z nim na kształtowanie dobrych obyczajów u wychowanka, jak również na problem samowychowania i wreszcie potrzebę ascezy zgodnej z nauką Ewangelii. Określenie środków i zasad wychowawczych wpłynęło na całokształt tradycji dotyczących wszystkich sfer życia w chrześcijaństwie i jednocześnie pozwoliło na przyswojenie najlepszych elementów paidei helleńskiej. Religia chrześcijańska była największą wychowawczą potęgą w dziejach i w swoich głównych założeniach pozostawała w harmonii $\mathrm{z}$ ideałami filozofii greckiej.

W tym procesie znaczący wkład ma refleksja Orygenesa. To dzięki dziełu tego wielkiego Aleksandryjczyka dochodzi do skutku kompleksowa asymilacja objawienia chrześcijańskiego i przeniknięcie do świadomości chrześcijan zdobyczy intelektualnych Hellenów. Zrodziła się paideia ewangeliczna, czyli pierwsza i najważniej-

${ }^{155}$ Contra Celsum I, 64. O Chryzypie Orygenes wspomina również tamże VIII, 51.

${ }^{156}$ Wyrażenie to spotykamy w De principiis III,1,13; Philocalia 27, 9. W tym ostatnim cytacie znajduje się formuła wprowadzająca charakterystyczna dla greckich komentatorów Iliady. Por. H. Erbse, Scholia Graeca in Iliadem, t. 5 (indeks), Berlin 1977, s. 409.

${ }^{157}$ Contra Celsum VIII, 31.

${ }^{158}$ Jest to wizja nakreślona przez św. Pawła. Por. 2 Tm 4, 7; 1 Kor 9, 24; Flp 2, 16. 
sza forma humanizmu chrześcijańskiego. Przyczyn powodzenia Orygenesa i jego sławy w sferze formacji intelektualno-duchowej należy szukać w fakcie, że nauczane wartości w istotnej części znajdowały postawę w intuicji pedagogicznej wspólnej dla pogan i chrześcijan. W przypadku niezwykłego didaskalosa z Aleksandrii dochodził czynnik nadprzyrodzony, którym się on kierował i wskazywał jako zasadniczy cel wszystkich wysiłków.

Orygenes jest autorem ujmującym w sposób kompleksowy poszczególne zagadnienia. Jest to powód, dla którego ten autor nie analizuje explicite problemu kształtowania nawyków. Mówi ogólnie o charakterystycznych przymiotach osoby ludzkiej, obdarzonej wolnością oraz potrzebie wykształcenia i formacji. Wola wydaje się ukształtowana, a o nawykach mówi się dosyć oględnie. Jednak paideia Orygenesowska implicite zakładała i dążyła do kształcenia woli i wyrabiania nawyków. Doktor aleksandryjski oparł swoje rozważania na tradycyjnych wątkach polemiki z heretykami, podkreślając zawsze wolność człowieka i dynamizm dziejów stworzenia. Kwestię wolnej woli połączył więc łukiem wydarzeń historii rodzaju ludzkiego i innych bytów rozumnych: od upadku w prehistorii po odnowę wszystkiego w Chrystusie. Bez tego ważnego filara systemu filozoficznego, egzegetycznego i teologicznego nie sposób zrozumieć specyfiki kontrowersyjnych sformułowań Adamancjusza, lecz także optymizmu, jaki przenika jego myśl. Refleksja Orygenesa zasadniczo odbiega od tego, czego spodziewa się współczesny czytelnik, zajmujący się procesem pedagogicznym lub formacyjnym. Pisarz aleksandryjski dołącza do innych starożytnych pisarzy Kościoła, którzy tworzyli raczej uzasadnienie o charakterze spekulatywnym pewnych zjawisk, przedstawiając nie tyle rzeczywistość, co wyobrażenie o niej. Ponadto pewnych kwestii w okresie późnego antyku po prostu w ogóle sobie nie stawiano. Wypróbowany i uświęcony wielowiekowym doświadczeniem system edukacyjny nie podlegał dyskusji. Podobnie było z rezultatami paidei prowadzącej do ukształtowania obywatela helleńskiej polis i światłego człowieka. Potwierdzeniem szczególnego znaczenia, jakiego nabrała problematyka wolnej woli i hexis stanowi fakt, że Aleksandryjczyk powraca do tej tematyki niejednokrotnie i to $\mathrm{w}$ dziełach o różnym charakterze i przeznaczeniu. Wzmianki i aluzje o charakterze pedagogicznym są niewątpliwie znaczące i świadczą o pewnego rodzaju mentalności, której znaczenia nie sposób pominąć.

\section{Il processo di formazione del libero arbitrio e l'acquisizione delle abitudini secondo Origene \\ (Riassunto)}

Il paradigma pedagogico fu presente nella mentalità e nelle istituzioni di tarda antichità, riflettendosi nella filosofia, nella letteratura e nell'arte. Per i cristiani il protagonista della paideia di Dio rivolta a tutti gli uomini era il Cristo - Logos. Nei primi tre secoli di storia cristiana i modelli pedagogici e formativi penetrano nella riflessione della Chiesa primitiva, ma giungono alla più significativa espressione nell'ambiente teologico alessandrino. Clemente e Origene sono i protagonisti dello sforzo più impegnativo e più vasto su questo campo. 
Volgono la loro attenzione alla creazione di una vera e propria paideia cristiana, in grado di stare all'altezza di quella ebraica e di quella pagana anche dal punto di vista culturale. Origene adotta la totalità della metodologia delle scuole filosofiche più in voga nel suo tempo. Offre perciò una paideia vasta e articolata, indirizzata alla conoscenza piu profonda delle Sacre Scritture che sono insondabili. L'esegeta è solo un pedagogo o iniziatore di un cammino che dovrà proseguire continuamente. La descrizione dello specifico processo formativo dell' Alessandrino viene offerto da Gregorio il Taumaturgo (III sec.) e da Eusebio di Cesarea (IV sec.). Le fonti non lasciano dubbi circa il compiersi di una prima assimilazione complessiva sia della rivelazione cristiana, sia della cultura antica. In questo contesto appare che la dottrina del libero arbitrio rappresenta un tema principale del sistema di Origene ed è uno dei suoi pilastri. La libertà è legata alla dignità stessa dell'essere razionale. Riportando gli argomenti a favore del libero arbitrio il dottore alessandrino indica la necessità di formare il giudizio per evitare le scelte disastrose. Origene inserisce il pradigma pedagogico per mantenere fermo il principio della giustizia di Dio e il libero arbitrio della persona umana. Appare che il giudizio e le pene hanno un valore educativo. Le abitudini (hexis - habitus) rimandano al concetto stoico della virtù. Anche in questo caso l'Alessandrino dimostra un'ottima conoscenza delle tecniche di argomentazione elaborate dalla indagine filosofica greca e ne usa nel modo articolatovari ellementi. Tuttavia costruisce il suo discorso in maniera autonoma delle fonti e con angolatura cristiana. Non va dimenticato però il complesso delle sue convinzione ardite e controverse che facevano discutere già nell'antichità. 